\title{
The impact of within-party and between-party ideological dispersion on fiscal outcomes: evidence from Swiss cantonal parliaments
}

\author{
Tjaša Bjedov $\cdot$ Simon Lapointe $\cdot$ Thierry Madiès
}

Received: 21 January 2013/Accepted: 17 December 2013/Published online: 22 January 2014

(C) Springer Science+Business Media New York 2014

\begin{abstract}
The impact of the fragmentation of executive and legislative bodies on the level and composition of government expenditure is a feature of politics that has attracted considerable attention from economists. However, previous authors have abstracted from two important concepts: ideology and intra-party politics. In this paper, we account for these two phenomena explicitly, and make two main contributions. First, we show that both intra- and inter-party ideological dispersion matter in explaining the level of subnational public spending. Therefore, it is improper to consider parties as monolithic entities. We also show that ideological dispersion matters especially for current expenditures, and not so much for investment expenditures. To do so, we construct a panel database (2003-2010) comprising data from a survey that quantifies the policy preferences of party members who were candidates in Swiss elections.
\end{abstract}

Keywords Political fragmentation · Public spending · Political parties · Ideology · Logrolling

\section{Introduction}

The impact of the fragmentation of executive and legislative bodies on the level and composition of government expenditure is a feature of politics that has attracted considerable attention from economists (Roubini and Sachs 1989; Kontopoulos and Perotti 1999;

\footnotetext{
T. Bjedov $\cdot$ S. Lapointe $\cdot$ T. Madiès $(\bowtie)$

Department of Economics, University of Fribourg, Bd. Perolles 90, 1700 Fribourg, Switzerland e-mail: thierry.madies@unifr.ch

T. Bjedov

e-mail: tjasa.bjedov@unifr.ch

S. Lapointe

e-mail: simon.lapointe@unifr.ch

T. Bjedov
}

CNRS-GATE, University of Lyon, 93, chemin des Mouilles, 69130 Ecully, France 
Freier and Odendahl 2012). Political fragmentation is present in all democratic countries, albeit to varying degrees. In most countries of continental Europe, where coalition governments are the norm, political fragmentation manifests itself in a large number of political parties both at the executive and legislative levels (Müller and Strom 2003). Ceron (2011) also reports, relying on case studies in at least 38 countries, that intra-party divisions and factions are an important part of the political lives of these countries. For its part, the European Parliament is becoming more fragmented owing to the enlargement of the Union. Indeed, the number of parties represented increased from 51 in 1979 to over 170 at the end of the first decade of the 2000s (Hix et al. 2009). We also recently observed explicit political fragmentation in parliaments of Westminster tradition, which are usually characterized by single party majorities. For example, in 2010, the UK saw its first formal coalition government since 1945 . $^{1}$ At the end of the first decade of the 2000s, Canada and Australia were governed by minority governments, in which the single governing party did not hold a majority of the seats. ${ }^{2}$ To stay in power, the largest parties in these three parliaments have had to bargain with other parties.

Numerous authors have studied the relationship between political fragmentation and fiscal outcomes. An early example is the paper by Roubini and Sachs (1989), which shows that coalition governments tend to spend more than single-party majorities, relying on the common-pool argument suggested by Weingast et al. (1981). Other more recent papers, reviewed below, confirm that more fragmentation is associated with more public spending or larger public deficits.

However, these papers all assume that political parties are monolithic entities, and most abstract completely from ideology. In this paper, we relax those two assumptions, and analyze the effect of both within- and between-party ideological dispersion on fiscal outcomes. The existing literature reveals that intra-party politics may affect policy outcomes. For example, Ceron (2011) shows that the existence of factions within parties will force parties to mobilize resources to satisfy these factions, such that it affects inter-party coalition negotiations, and thus fiscal outcomes. To our knowledge, the concept of intraparty politics is not addressed in the current literature on political fragmentation. In practical terms, we decompose the total variance in ideological scores for individual candidates running in Swiss elections into two components. First, to find intra-party variance, we calculate the variance of members' ideological scores within each party. Then, we define intra-party ideological dispersion as the mean of these variances. Second, we define inter-party variance as the variance of the parties' average ideological positions. We do so by compiling an original database at the sub-national (cantonal) level using data from a survey (Smartvote) quantifying the preferences of individual party members that were electoral candidates.

Our main contribution is to show that both intra- and inter-party ideological dispersion are factors that are significant in determining fiscal outcomes. In particular, we find that intra-party ideological dispersion increases public spending, while inter-party ideological

\footnotetext{
1 Short-lived minority governments and pacts occurred between 1974 and 1978 and in 1997 (Maer 2010).

2 Australia had its first minority government in over 70 years in 2010, when the Labor Party and the coalition led by the liberals both failed to capture a majority of seats (Horne 2010). However, minority and coalition governments are more common in Australian sub-national jurisdictions. For its part, Canada was led by minority governments from 2004 to 2011 (the Parliament of Canada's website has details on the length of all minority governments in Canadian history: http://www.parl.gc.ca/Parlinfo/compilations/ parliament/DurationMinorityGovernment.aspx). Hung parliaments are more common in Canada than in Australia, although this 7-year-long string of minority governments was a first. Before that, a minority government ruled for 6 months in 1979 .
} 
dispersion decreases it. We also find that these results are stronger for current expenditures than for investment expenditures.

Our econometric results are discussed in greater detail in Sect. 6. Before turning to this discussion, however, Sect. 2 reviews important contributions to the literature on political fragmentation, while Sect. 3 reviews contributions related to intra-party politics and ideological dispersion. This latter section also provides the basis for the theoretical argument underlining our empirical findings. Section 4 highlights features of the Swiss political system that are particularly relevant to the topic at hand. Then, Sect. 5 describes the data sources and the methodology used to estimate ideological dispersion. Conclusions are given in Sect. 7.

\section{The effects of fragmentation and coalition governments on fiscal outcomes}

Social scientists have long shown interest in the relationship between the characteristics of political entities such as parliaments and governments around the world and the corresponding fiscal outcomes. For example, Alesina and Tabellini (1990) consider policymakers with different preferences that alternate in office, and use government debt as a strategic tool to influence the decisions of their successors. Persson and Svensson (1989) consider a related model in which, due to time-inconsistent preferences, a conservative government may borrow more when it knows the next government will be expansionary. This section will review some contributions related to the ideological position of governments (i.e., left- vs. right-wing governments), the type of government (coalitions vs. majorities), as well as the fragmentation of the executive and legislative branches (i.e., the number of parties represented).

One could suspect that the spending patterns of right- and left-wing governments will differ. Empirically, Roubini and Sachs (1989) show that leftist governments tend to spend more in OECD countries. Mulas-Granados (2003), for his part, finds that ideology is the strongest predictor of the fiscal policy stances of European governments, and that left-wing governments on that continent are less likely to cut public investment and employment. Tavares (2004, p. 2447), using a panel of large fiscal adjustments in OECD countries, finds that "the left tends to reduce the deficit by raising tax revenues while the right relies mostly on spending cuts." Rudolph and Evans (2005) argue that conservative governments bear heavier ideological costs when increasing public spending, such that conservatives will have to rely to a greater degree on trust between them and their constituents. They show, using a US dataset, that "[t]he effects of political trust among conservatives are of such sizable magnitude that they frequently erase the ideological gap between liberals' and conservatives' level of support for government spending" (Rudolph and Evans 2005, p. 668).

Another strand of the literature explores political fragmentation, including procedural fragmentation and fragmentation in the number of coalition parties, both in the executive and legislative branches. These papers mostly rely on the common-pool argument, which Weingast et al. (1981) coined as the "law of $1 / n$ ". This argument states that, because public projects often have localized benefits for constituencies but universal costs, governments have a tendency to overspend. Alternative theoretical explanations include Tsebelis's (2002, p. 188) veto players argument. This argument states that the existence of veto players delays fiscal adjustments, such that some "policy inertia" exists. Spolaore (1993), relying on the veto players argument and extending the wars of attrition model (see Alesina and Drazen 1991), shows that coalition governments may delay fiscal adjustments 
longer than single-party majorities. Padovano and Venturi (2001), for their part, find that more fragmented governments are less likely to engage in wars of attrition, when taking into account both the government and the opposing coalitions. Hallerberg et al. (2009) provide a framework for classifying governments according to the powers held by individual ministers. In the first category, named fiefdom, each minister wields considerable power over spending in his domain, resulting in severe common-pool problems. To reduce this problem, governments can instead choose delegation to a finance minister, or commitment to strict budgetary norms.

A large number of authors in the past two decades have tested the common-pool argument empirically. Ricciuti (2004) offers a comprehensive literature survey. One way of distinguishing governments in the context of the common-pool argument is by classifying them in coalitions and majorities. In a coalition government, the argument is that each party in the coalition takes into account only the costs bearing on its own constituents and not its allied parties (Freier and Odendahl 2012). Roubini and Sachs (1989) were among the first to test this question empirically. These authors find that coalition governments spend more than single-party governments, using a panel of OECD countries between 1960 and 1985. Freier and Odendahl (2012) make an argument in opposition to this early finding, using a regression discontinuity approach with data from German municipalities over two electoral cycles (1996-2002 and 2002-2008). In fact, they find that absolute majorities spend more than coalition governments. They exploit a discontinuity in election results, by comparing absolute majorities that barely won the last decisive seat with coalition governments that include a party that almost made the cut-off to govern alone.

Instead of just differentiating coalitions from majorities, Kontopoulos and Perotti (1999) focused on cabinet size, as captured by the number of spending ministers. Indeed, the common-pool problem may also exist in a majority government with a large number of spending ministers. Using a panel of 20 OECD countries from 1960 to 1995, they find that the greater the number of ministers competing for the common pool of resources, the larger will be the budget deficit. De Haan et al. (1999) find a similar relationship between the number of political parties in government (i.e., coalition size) and the growth of the central government debt-to-GDP ratio, also using a panel of OECD countries from 1979 to 1995. Perotti and Kontopoulos (2002) include both types of fragmentation: the number of ministers and the size of the coalition. They find (again with a panel of 19 OECD countries, from 1970 to 1995) that cabinet size is the strongest determinant of fiscal policy, with particularly strong effects on transfers. Using a panel of Swiss cantons between 1980 and 1998, Schaltegger and Feld (2004) find a positive effect of cabinet size on cantonal government expenditures. However, they are unable to draw strong conclusions on the effects of coalition size (again, defined as the number of parties in the coalition) on cantonal public expenditures.

The literature thus offers some evidence that political fragmentation affects fiscal policy. However, other papers have cast some doubt on the robustness of the results. For example, Elgie and McMenamin (2008) show that the results depend on the sample choice. The authors successfully replicate the results of previous papers using a panel of OECD countries, but fail to do so when adding non-OECD countries (in an unbalanced panel, ranging from 1975 to 2004). They explain this result by entering a variable measuring the institutionalization of the country, defined as the age of the democracy. They argue that political institutions are more important in older democracies. Therefore, in those countries, political fragmentation does affect the budget surplus, but not in younger democracies. In earlier work, de Haan and Sturm (1997), using a panel of OECD countries between 1982 and 1992, also fail to replicate the results of Roubini and Sachs (1989). As mentioned above, de Haan 
et al. (1999) do find a relationship between coalition size and public debts. However, they fail to replicate the results of Roubini and Sachs (1989) when using the latter's classification of governments. In a panel covering local and state governments in the US, Gilligan and Matsusaka (1995) find that the number of seats in the legislatures has a positive impact on public spending. However, that finding is only true for the upper chamber.

\section{Ideological dispersion and intra-party politics}

Most models described above define fragmentation in a limited sense, namely by the number of parties in the coalition. That definition captures the common-pool argument, or the extent to which individual policymakers internalize the costs of their decisions (Perotti and Kontopoulos 2002). However, the relationship between political fragmentation and fiscal policy also depends on ideology. The idea that ideology matters was explored by Volkerink and de Haan (2001). These authors argue that large ideological differences in government matter because they make compromise more difficult. They also argue that, when ideological differences in the parliament are large, the opposition is weaker, thus granting more freedom for the government to impose its policies. Empirically, however, the authors find no evidence that ideological differences affected public spending in a panel of 22 OECD countries between 1971 and 1996. In a more recent paper, Eslava and Nupia (2010) argue that the lack of evidence resulted from an improper specification. In particular, they assert that ideology and size fragmentation (i.e., the number of parties in parliament) are inter-related, such that econometric analyses must allow for an interaction between the two. In fact, with a panel of 22 presidential democracies for the 1978-2005 period (including developed and developing countries), they find that size fragmentation affects public spending only when some ideological polarization between parties is present. They also find that this polarization tends to increase public spending. ${ }^{3}$

Lindqvist and Östling (2010) also study the relationship between ideological dispersion (which they call polarization) and fiscal policy, albeit taking a different approach. These authors use data from interviews with voters carried out between 1995 and 2002 to estimate ideological dispersion in a cross-section of 74 countries. They find that this measure of ideological dispersion, derived from the perceptions of the electorate, has a significant negative effect on government size. The advantage of their approach is that their data measure political preferences directly instead of relying on proxies for them (ethnicity or religion, for example). However, in contrast to our new dataset, their data are only available for the electorate and not for politicians. Furthermore, as acknowledged by the authors, the link between polarization in the electorate, polarization in the legislature, and public spending is not completely understood, although they find that a polarized electorate is not associated with a fragmented legislature.

The current literature implicitly assumes that parties are monolithic entities and are the only decision-making units. The two papers cited in the previous section measure ideological dispersion (i.e., polarization) only between parties (Eslava and Nupia 2010), or take into account only the ideological dispersion in the electorate but not within political parties (Lindqvist and Östling 2010). However, this rationale abstracts from intra-party politics.

\footnotetext{
3 These authors use two measures of ideological polarization. The first is a variable describing the maximum distance between the governing parties (the executive party and the three main coalition partners) on the usual left-right scale (taking a value of two if one party is at the right end and another at the left end), while the second is the SD of the ideology of the three main governing parties.
} 
The idea that parties are not unitary actors is not new. In earlier work, Belloni and Beller (1976) argue that the study of party factions has been neglected relative to parties and interest groups, because these latter groups have more obvious structures. ${ }^{4}$ However, they also argue that party factions play an important role in the political institutions of many countries. They point out that in some cases, such as in Italy and Japan, factions have a long tradition and are almost official groups. For a recent literature survey on intra-party politics and factions, see Ceron (2011).

To our knowledge, no existing papers have studied the relationship between ideological dispersion, intra-party politics, and fiscal outcomes. We argue that the ideological dispersion within parties impacts policy-making just as does dispersion between parties. More specifically, we argue that intra-party ideological dispersion affects public spending through two main channels: political factions, and logrolling (i.e., vote-trading).

\subsection{Political factions}

The first channel rests on the theory of factions, which relies on the same type of commonpool argument outlined above, but does so within parties. The literature showed that patronage is one reason for the existence of factions, but that factions could also be classified along the traditional left-right scale (Bettcher 2005; Golden and Chang 2001; Zuckerman 1979). Furthermore, Ceron (2011, p. 30) shows that "factions hold different preferences and conflicting views about party platform" (see also Debus and Bräuninger 2009). Lower unity within political parties will lead to important costs, as parties will mobilize resources to satisfy some of its factions to avoid party fissions. Party leaders can either mobilize internal resources within the party, or promise to target some public spending towards issues that are relevant to the factions. Following Ceron (2011), we argue that higher intra-party ideological dispersion should be associated with a larger number of factions, or factions that differ significantly from each other. To summarize the argument, higher intra-party ideological dispersion leads to more factions or more different factions, which in turn leads to more promises for targeted policies from party leaders to these factions. In turn, these policy accommodations should lead to more spending overall.

In a similar line of reasoning, the existence of factions (or simply the existence of ideological divergences) within parties may also affect negotiations between parties to form broad coalitions or alliances on certain legislative projects (see Laver and Shepsle 1990, for example). Pedersen (2010) distinguishes between parties who favor policy purity versus policy influence. She argues that influence-driven parties that are ready to make concessions may be more likely to be included in coalitions, while policy-pure parties, less ready to yield on their positions, will be excluded and will have to influence policy by indirect means, such as public debate, or maybe, in the case of Switzerland, referendums. In a similar fashion, we argue that more ideologically dispersed parties have greater strategic flexibility, thus facilitating coalition bargaining or the implementation of deals on specific legislative

\footnotetext{
${ }^{4}$ More recently, the emergence of the Tea Party, an American grassroots movement mostly associated with the Republican Party, is another example of a somewhat official faction, now even recognized as an official Congressional Member Organization (CMO). The relationship between the Tea Party movement in the public at large and the CMO is not clear, with many members of the former not recognizing the latter. However, the members of the CMO are supporters of the larger movement. Party factions also exist in France. Indeed, major French parties are characterized by smaller factions. For example, the Socialist Party has a social-democratic, more moderate branch, but also includes members of a more radical leftist tradition. Similarly, the Union pour un mouvement populaire is comprised of a socially conservative branch as well as a more market-oriented faction.
} 
proposals. Warwick (2000), in a similar argument, advances the notion that parties have a "policy horizon", which defines the range over which parties are ready to compromise in order to form a government. Other authors, including Back (2008), argue that such ideological dispersion has a negative impact on coalition-building. The existence of opposing views regarding the link between intra-party factions and inter-party negotiations shows that the specific institutional context should be taken into account in our analysis.

\subsection{Logrolling and vote-trading}

The second channel through which intra-party ideological dispersion affects fiscal outcomes relies on the theory of logrolling and vote-trading. Miller (1999) defines logrolling as "the exchange of political support, particularly in the legislative process." Miller (1999) also distinguishes between "explicit" logrolling as experienced in, for example, the US, and "implicit" logrolling, the latter "occurring in the construction of legislative programs and party platforms or manifestos, within one-party cabinets, and in inter-party negotiations leading to coalition governments." For logrolling to occur, there must exist pairs of legislative projects for which some members of parliament win by exchanging votes. Carrubba and Volden (2000) develop a game-theoretical model of logrolling, detailing conditions under which logrolling coalitions are sustainable.

Logrolling may occur between any pair or group of members of parliament. In a country where party discipline is sufficiently weak, it can take place both between members of different parties and members of the same party. How would ideological dispersion affect logrolling? We argue that, within parties, trust between members is strong enough that coordination costs are relatively low. Greater trust implies that individuals are more likely to believe that their partners will not defect from their agreement. Furthermore, we argue that, as intra-party ideological dispersion increases, trading possibilities are more frequent. Indeed, some dispersion raises the chance of having preferences different from other party members, thus creating trading opportunities. At the other extreme, perfectly coinciding ideological positions would correspond to a situation in which there is nothing on which to trade. Since parties are more ideologically cohesive than parliament as a whole, less trust between partners is needed to have sustainable logrolling coalitions. In contrast, when between-party ideological dispersion rises, logrolling should occur relatively less often. Indeed, trust between members of different parties being lower, coordination costs are higher.

To briefly summarize, we argue that intra-party ideological dispersion should positively affect coalition building, and thus increase public spending. In contrast, inter-party ideological dispersion, at least in Switzerland, should have a negative impact on coalitionbuilding, thus reducing public spending.

\section{Swiss institutional and political background}

The institutional arrangement of Switzerland allows economists and political scientists to benefit from a sort of natural laboratory in which 26 sub-national governments have large fiscal autonomy (Kriesi and Trechsel 2008), but share the same institutional and socioeconomic context. Indeed, this country is organized in a decentralized federal system with three layers of government: federal, cantonal, and municipal (known as communes). The country comprises 26 cantons of different cultures and languages, enjoying a relatively high level of independence from the federal government (Kriesi and Trechsel 2008). Cantonal governments also enjoy considerable fiscal autonomy and account for a large 
portion of total public spending in Switzerland. For example, in 2008, cantonal governments' revenues accounted for $24.4 \%$ of total government revenues, with cantonal governments enjoying full discretion on the entirety of that revenue. ${ }^{5}$ Finally, studying a single country at a time can also circumvent the issue of coding different government systems, a problem that could be exacerbated by adding an ideological component to the analysis.

Our paper focuses on the cantonal governments and parliaments. The parliaments of the 20 cantons included in the analysis are unicameral with a varying number of elected members (with an average of 120 seats; see Table 2, below). Each canton has an executive council that is also elected by the voters at large. Kriesi and Trechsel (2008) offer a more complete description of the Swiss political system, and of the factors that contributed to its particular development. The remainder of this section will focus on important distinctive features that are particularly relevant to our analysis.

First, the entrusting of executive power to a council (called "Conseil d'Etat" in French or "Kantonsregierung" in German) without a clear leader is unique to Switzerland. Indeed, most countries vest considerable executive power in a single person, such as a president. In the context of our paper, this distinction is important because all the parties represented in this council share executive power and can influence the elaboration of the budget directly. The minister of finance is one among other decision makers, such that the common-pool problem is not internalized fully. Moreover, the budgetary process is subject to a number of fiscal rules that limit the discretionary power of the ministers (see Feld and Kirchgässner 2006 for examples of fiscal rules). In the terms of Hallerberg et al. (2009), Swiss subnational governments would be classified in the commitment category. In most countries, the executive power is held either by a single party or by a coalition assembled through negotiations between parties. In a slight abuse of language, we will refer to the parties in the executive council as the governing coalition, even though they do not form a coalition in the usual sense. We will refer to the other parties as the fringe group. In our data, the governing coalition includes between 65 and $100 \%$ of the members of parliament. In Switzerland, the executive council does not have to face periodic votes of confidence from the parliament. Therefore, there is no need for parties to build an official coalition. Instead, parties may build ad hoc coalitions that can change often and be valid only for a certain number of projects. Bachtiger et al. (2006) tallied the coalition patterns in the Swiss federal government between 1996 and 2005, and found that the coalition comprising the four parties in government (those with executive power) account only for $17 \%$ of coalitions.

Another important feature of Switzerland's political system is the remarkably high collegiality of the legislature (Kerr 1978). It is a system in which consensus and stability are important (Church and Vatter 2009), despite considerable fragmentation (Ladner 2001). Kriesi and Trechsel (2008) argue that this feature stems from the tradition of direct democracy in Switzerland. Indeed, before presenting a budget or a new law, the government devotes substantial time consulting not only other political parties but also a wide variety of interest groups. This process ensures that the project is accepted widely, and not subject to a popular vote (referendum) after adoption. Consequently, direct democracy leads to the inclusion in the decision process of all political parties that can make a credible referendum threat (Kriesi and Trechsel 2008). In the terms of Tsebelis (2002), referendums supply veto player roles for political actors who can organize them. Moreover, collegiality is reinforced by the fact that parties in the executive branch must find a way to collaborate.

\footnotetext{
5 Swiss sub-national governments enjoy full discretion on the tax rates and the levels of tax allowances and reliefs (reductions in the amount owed). For more details, see the OECD fiscal decentralisation database, available at http://www.oecd.org/tax/federalism/oecdfiscaldecentralisationdatabase.htm.
} 
Political fragmentation and ideological dispersion are closely related to party discipline. If a party member is not satisfied with the party's position, he can always decide to vote against the rest of his party. The willingness of party members to obey party leaders will vary according to their outside options. Indeed, we can safely assume that a politician who could resign and immediately find lucrative employment in the private sector would be more willing to face the consequences from the party than a politician with limited options out of politics. ${ }^{6}$

In Switzerland, cantonal politicians are not professionals, and often even keep their previous jobs. For this reason, we should expect low party discipline, which favors logrolling, as explained in the previous section. Indeed, Jeitzinger and Hohl (1997), Hertig (1978) and Lanfranchi and Luthi (1999) show that Swiss parties, especially those in the center and on the right wing of the political spectrum, exhibit little party discipline. This feature contributes to the importance of accounting for ideological dispersion when analyzing the relationship between political fragmentation and fiscal outcomes. Moreover, since party discipline is far from perfect in most countries, ideological dispersion should also be important in the analysis of other countries.

The impact of both institutional and political features of Switzerland on fiscal outcomes has been the focal point of a number of studies. Feld and Kirchgässner (2000) surveyed a number of empirical studies showing that direct democracy affects public spending. First, citizens have better information on political issues, which reduces the ability of politicians to behave as rent seekers. Second, the authors argue that citizens are less selfish and feel more responsible for their own communities, thus more readily accepting personal material losses resulting from political choices. This second argument is in line with Rudolph and Evans (2005) and Hetherington (2006). Feld et al. (2003), using a panel of 26 Swiss cantons over the 1980-1998 period, show that greater decentralization and stronger institutions of direct democracy reduce total cantonal revenue per capita. Feld and Kirchgässner (2006), using a panel dataset over the same period, show that fiscal constraints reduce public budget deficits while direct democracy reduces public debt. Fiscal constraints were also studied in the US by Poterba (1994), who finds that "more restrictive state fiscal institutions [...] are correlated with more rapid fiscal adjustment to unexpected deficits" (Poterba 1994, p. 799). Using a panel of Swiss cantons between 1980 and 1998, Schaltegger and Feld (2004) find a positive effect of cabinet size on cantonal government expenditures.

\section{Description of variables used}

As mentioned in the previous sections, the key contribution of our paper is that it acknowledges the ideological dispersion between and within political parties. This section describes the construction of our measures of ideological dispersion. It also describes the more traditional political fragmentation variables, and presents the various control variables included in our econometric models.

\subsection{Political dispersion and fragmentation}

Hug and Schulz (2007) discuss different methods for estimating the positions of Swiss politicians and political parties on the usual left-right scale. These methods use data from the parties' voting recommendations, the results of roll-call voting, and the contents of

\footnotetext{
${ }^{6}$ Following the 2011 federal elections, close to one-third of the National Council members were new. At that date, the median tenure in parliament was slightly under 4 years, highlighting the fact that turnover is high in Swiss politics, at least at the federal level.
} 
party manifestos. We depart from these methods of positioning elected representatives and instead consider directly their ideological positions on a multitude of issues to construct a composite index of their political profiles. For that purpose, we use data from a survey of Swiss politicians called Smartvote. Smartvote is an online voting advice application for Swiss voters that was first launched in the run-up to the 2003 Swiss federal elections, and used again for the elections in 2007 and 2011. Prior to the election, the Smartvote team asks electoral candidates to answer questionnaires on a wide range of topics. ${ }^{7}$ The political profiles of the candidates are generated from their answers to the questionnaire. Smartvote also builds a scatter plot called Smartmap that places each candidate on two axes. The $x$ axis represents the usual left-right dimension and the $y$ axis represents the conservativeliberal scale. To locate the $x-y$ coordinates for each candidate, the Smartvote team uses correspondence analysis. The Smartmap displays the relative positions of the candidates and facilitates comparisons between parties and individuals. ${ }^{8}$

In our paper, we use the coordinate corresponding to the most important axis indicated by the correspondence analysis. In each election year, the chosen axis explains about $80 \%$ of the variation in the answers of the candidates. The coordinate is rescaled as an index that varies from 0 to 1 . We use the political profiles of candidates for both the lower and upper chambers of the federal legislature, but these candidates are disaggregated by canton and party. For each party in each canton, we thus obtain an average ideological score, along with the ideological dispersion within the party. As mentioned in the previous section, politicians consult a wide range of stakeholders before proposing new laws, including other political parties, and most likely members of their own parties. For this reason, we use the ideologies of the political parties at large (i.e., all candidates), and not only elected members.

With the ideological indices and dispersions obtained for each election year, we calculate the total variance, as well as a decomposition of the variance (intra- and inter-party) of the ideological positions. ${ }^{9}$ Intra-party variance is defined as the average of the variances of the ideological position within parties, weighted by the number of seats held by each party in the cantonal parliament. Inter-party variance is defined as the variance of the parties' average ideological positions, again weighted by the number of seats held by each party in the cantonal parliament. The position of a political party is calculated as the average of its members' profiles. ${ }^{10}$ Furthermore, as mentioned earlier, we split the political parties into two groups: a governing coalition and a fringe of often-smaller parties. We calculate the variance decomposition for the governing coalition group alone, as well as for all parties combined. We thus obtain two measures for each group (INTRACOAL and INTERCOAL for coalition parties, and INTRAALL and INTERALL for all parties). We use data from the Swiss Federal Statistical Office for the party breakdown of the cantonal parliaments and executive councils from 2003 to 2010 (the years for which the remainder of the data are available).

\footnotetext{
7 The 2011 questionnaire is available on the Smartvote website at http://smartvote.ch/11_ch_nr/ questionnaire.

${ }^{8}$ During the electoral campaign, voters can answer the same questionnaire on the Smartvote website and have their answers compared to those of the candidates. As a result, Smartvote matches each voter with a specific ranking of all competing candidates.

9 Further details are provided in a longer version of this paper, available on request.

10 The composition of the parliament varies following every cantonal election (or by-election), while ideology scores (the average score of, and variance within, each party) stay constant between each federal election. For this reason, our variables have at least some variation every year, if only for composition effects.
} 
Figure 1 illustrates both the ideological position (measured by the median) and the dispersion (measured by the quartiles and the range) of the main parties in the Canton of Zurich. ${ }^{11}$ It shows that ideology varies both within parties, as seen in the large ideological span of some parties, and between parties. The figure also shows that some parties have overlapping ideological distributions. Table 1 summarizes the inter-cantonal differences in party positions. It shows that the mean ideology of the four main parties in Switzerland differs across cantons, but we also see that differences across parties are larger.

The richness of our database allows us to construct variables measuring the ideologies of individuals and parties in ways that differ from previous papers. It is therefore important to discuss the results that we can expect from our estimations. The decomposition of the variance in within- and between-party components allows a ceteris paribus interpretation of their effects. In Sect. 3, we argued that intra-party ideological dispersion increases public spending. We also argued that, at least in the Swiss case, inter-party ideological dispersion should reduce public spending.

To stay in line with the literature reviewed earlier, we also construct a measure of fragmentation similar to what is called size fragmentation in the literature (Volkerink and de Haan 2000; Perotti and Kontopoulos 2002). More precisely, we use the effective number of political parties (Laakso and Taagepera 1979). This measure is in essence the inverse of a Herfindahl-Hirschman concentration index. This index (ENPCOAL and ENPALL) takes a value of one for a parliament in which a single party holds all of the seats. It is constructed in line with the current literature, so we expect a larger effective number of political parties to be associated with more public spending.

\subsection{Dependent variables and control variables}

The rest of the data come from the Swiss Federal Statistical Office, and covers the period 2003-2010. Our dependent variables are total cantonal public spending per capita and as a percentage of total cantonal GDP; both were taken without interest charges. As explained later, we will also estimate the model using public spending disaggregated by their purpose: investment expenditures and current expenditures.

We also add economic and political control variables to our models. To account for the political decision-making process, we enter the number of seats in the cantonal parliament. The previous literature documented a positive correlation between the number of parliamentary seats occupied and political fragmentation. To capture the fact that governments can manipulate spending over electoral cycles, we also include a dummy variable for election years. Finally, we control for the ideological biases of parties in the governing coalition by including the average of the ideological positions of these parties.

To control for the economic context, we include the lagged net public debt per capita, which we expect to affect public spending negatively. We also control for GDP per capita. ${ }^{12}$ We also include the share of the dependent population in total population. We define the dependent population as the sum of people 20 years old and younger and of people 60 years old and older. The empirical literature usually shows that this variable increases public spending since it represents stronger demand for spending for schooling and social welfare programs. Finally, we include the unemployment rate for the time period considered, which we expect to increase public spending.

\footnotetext{
11 The box plots for other cantons are available from the authors.

12 Cantonal GDP data are not available for every year. We obtain data for GDP per capita from the Swiss Federal Statistical Office for 2003-2005. For the years from 2006 to 2010, we extrapolate the data using the national growth rate of GDP per capita, assuming that the growth rate is similar across cantons.
} 


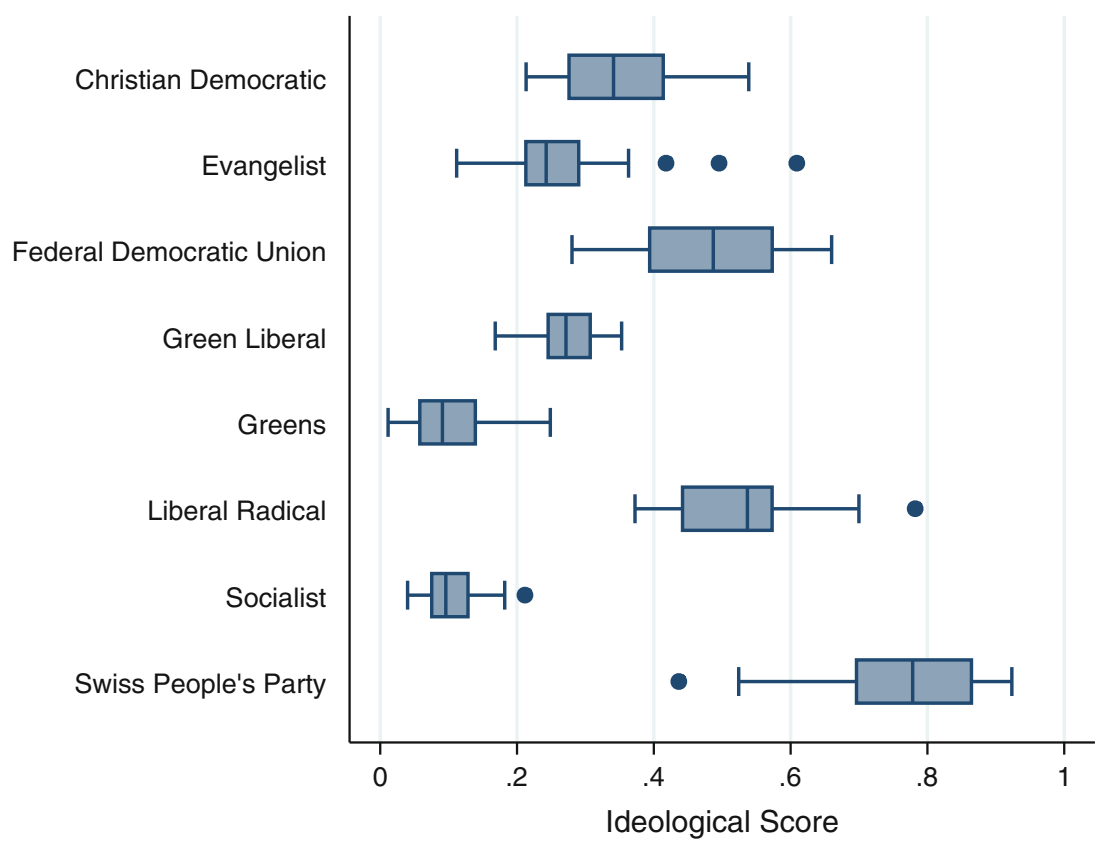

Fig. 1 Ideological ranges of the main parties in Zürich

We also control for some institutional features of Switzerland. First, we control for the fiscal decentralization in the canton (FEDERALISM), by including the ratio of local spending to the sum of local and cantonal spending (both without interest charges). We also control for territorial fragmentation by using a proxy variable (TERRITORIALFRAG), which is calculated by dividing the number of municipalities by the cantonal population. We cannot control directly for the presence of mandatory referendums, an important aspect of Swiss direct democracy, since it stays constant throughout our sample period, and thus is captured fully by the fixed effects. Feld and Kirchgässner (2006) also encounter this problem in their analysis. Because their primary variables of interest would have been completely or partially captured by fixed effects, they decide not to include the latter. Since their model would be inappropriate, they use cantonal dummies as instruments to cope with possible endogeneity. Since these institutional variables are interesting to us only as control variables, we decide to rely on fixed effects and not to include controls already captured by fixed effects. Table 2 summarizes the variables included.

\section{Econometric results}

This section presents the regression estimates obtained from a variety of models. We obtain these estimates using standard fixed effects models ${ }^{13}$ on our panel of 20

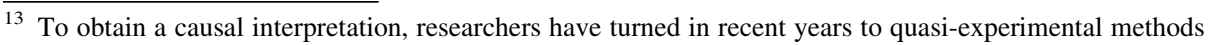
such as instrumental variables or regression discontinuity designs. Obviously, we would welcome the use of such methods to study the relationship between ideological dispersion and fiscal outcomes. However, our specific framework does not allow for these. The presence of endogeneity not being obvious, we believe that our results, while needing to be interpreted with some caution, are still interesting.
} 


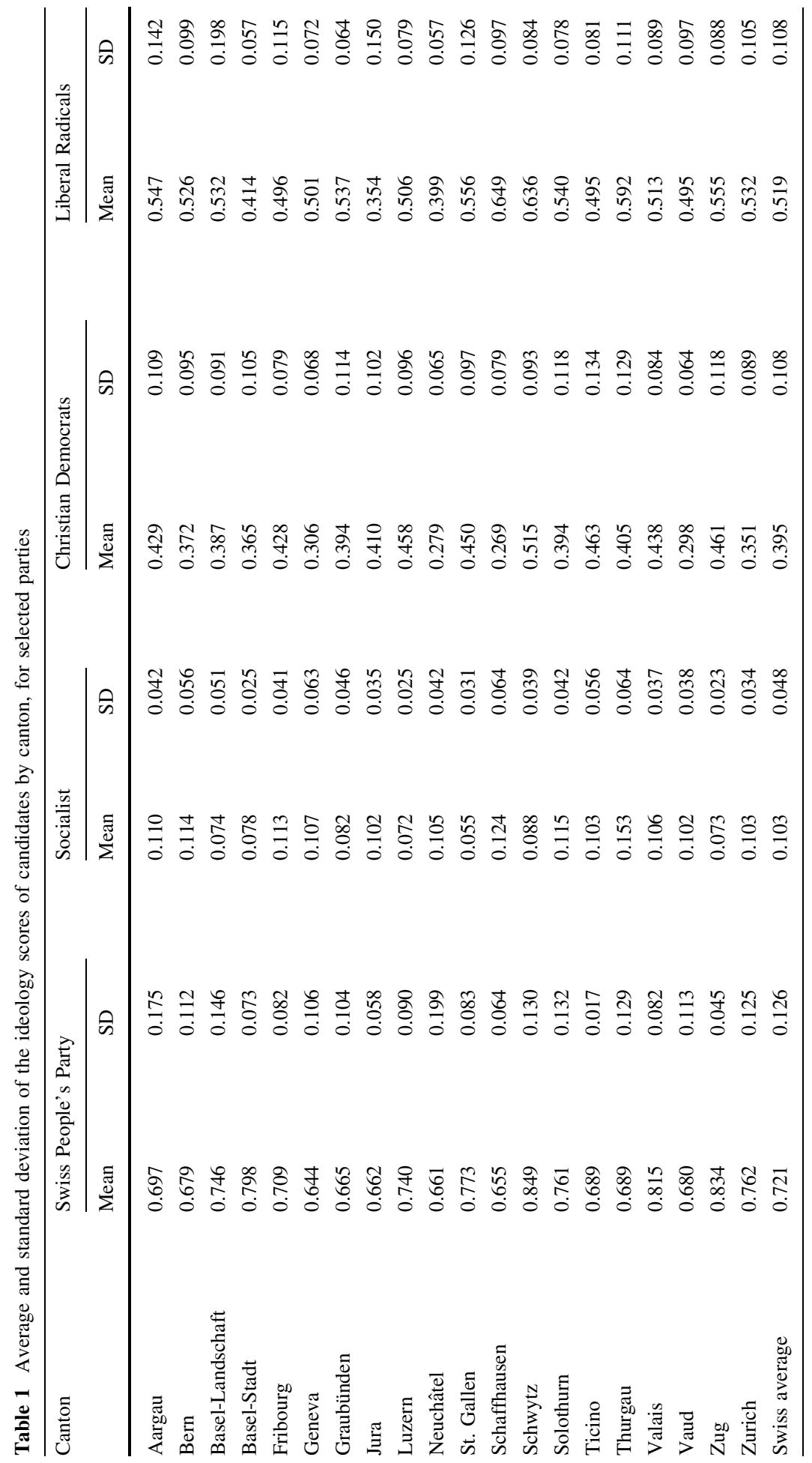




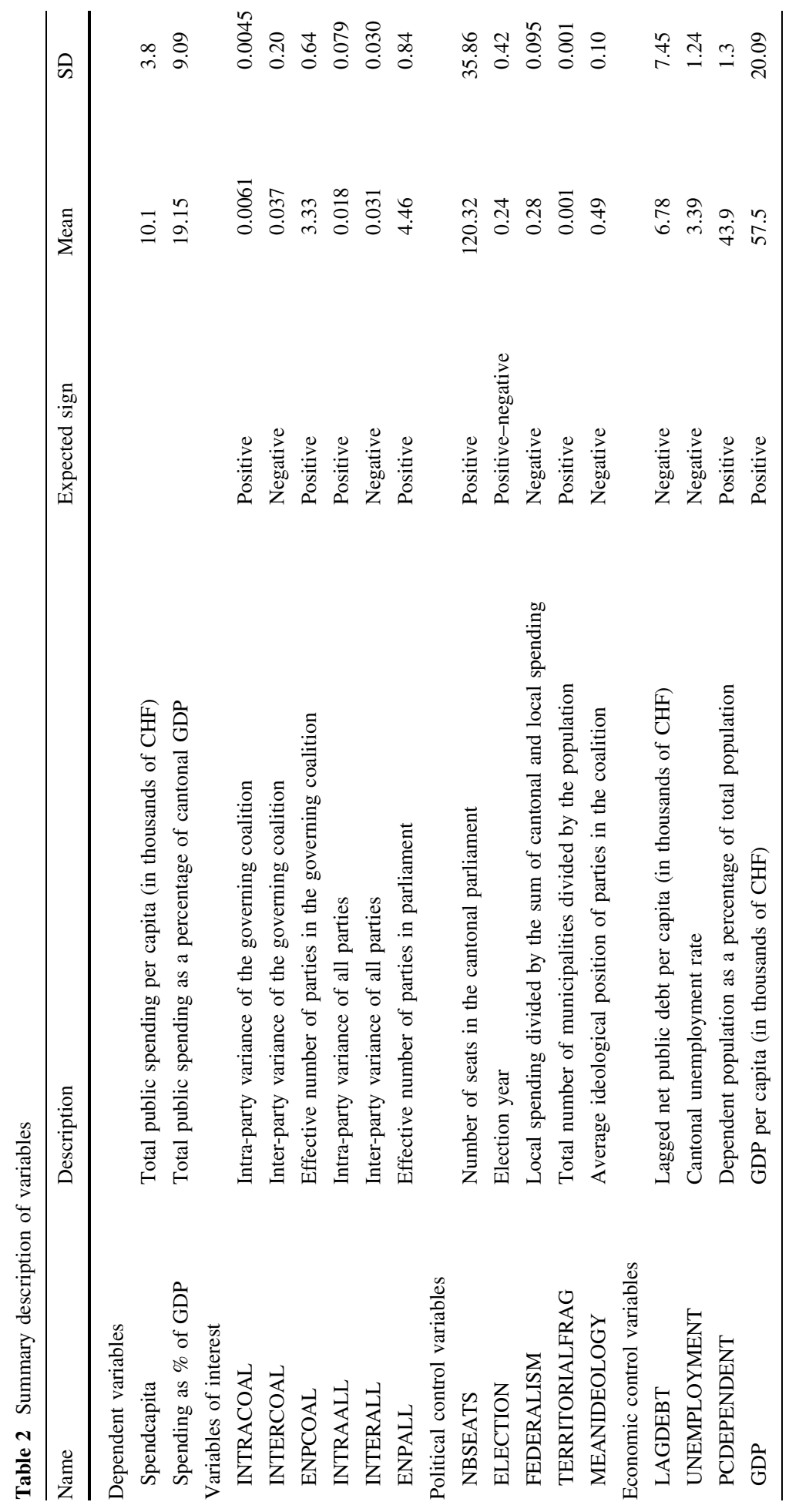


cantons over 8 years. ${ }^{14}$ All models are estimated with clustered robust standard errors.

Our starting point is to estimate the effect of total ideological variance on public spending. The results are available in the appendix. We find only limited evidence that total variance has a negative impact on public spending. Indeed, this result is not robust to the specification of the model. Like much of the literature, we thus fail to find a strong linkage between total ideology dispersion and public spending. This lack of result further motivates the exploration of other avenues of research, such as intra-party politics. We reviewed the recent literature on that topic and concluded that we should not treat inter-party dispersion in the same manner as intra-party dispersion (see Sect. 3) Therefore, we continue our analysis using ideological dispersion separated into its two components: inter- and intra-party variance.

Our main model includes the governing coalition variables (INTRACOAL, INTERCOAL, ENPCOAL), in addition to the control variables identified in the previous section. Estimation results are shown in columns one and two of Table 3. With both dependent variables, we obtain significant coefficients of the expected signs for both intra- and interparty dispersion (INTRACOAL and INTERCOAL). In particular, we observe that intraparty ideological dispersion in the coalition group is associated with more public spending. The size of the coefficient is difficult to interpret, because the variable is not measured in any of the usual units. However, we can obtain a general idea of its scale. If we could increase the coalition group's intra-party dispersion by one times its standard deviation, while keeping everything else constant, we would observe an increase in public spending per capita of 754 francs. ${ }^{15}$ Using the model with the alternate dependent variable would lead to an increase of 0.70 percentage points in public spending as a percentage of cantonal GDP. Thus, the effect is also economically significant.

In both regressions, we also find that inter-party ideological dispersion in the coalition group is negatively associated with public spending, although the effect is smaller than the one from intraparty dispersion. As above, we can obtain a idea of the scale of the estimated coefficient. If we could increase the inter-party dispersion in the coalition group by one times its standard deviation, while keeping everything else constant, we would observe a reduction in public spending per capita of 442 francs. ${ }^{16}$ Using the model with the alternate dependent variable, the estimated coefficient would lead to a decrease of 1.26 percentage points in public spending as a percentage of cantonal GDP. ${ }^{17}$ As explained in depth in Sect. 3, the results for intra- and inter-party dispersion may depend on intra-party dynamics, inter-party negotiations, and logrolling opportunities.

As a robustness check, the second model we estimate (columns 3 and 4 of Table 3) includes all of the previous variables, but considers all political parties instead of only those in the governing coalition. As discussed in Sect. 4, in Switzerland all parties may play roles in the legislative process, especially if they are able to organize referendums. For this reason, it could be important to also include the smaller parties in the analysis. Additionally, in some cantons, large parties such as the Swiss People's Party (SVP) ${ }^{18}$ are not elected to the executive council even though they are represented in the legislature.

\footnotetext{
14 Ticino is an exception. For that canton, we are able to collect observations for 4 years only, thereby limiting the number of observations suitable for our model.

15 Using the average exchange rate over the period, this amount corresponds to 490 euros or 635 US dollars.

${ }^{16}$ Using the average exchange rate over the period, this amount corresponds to 287 euros or 372 US dollars.

17 The effect of intra-party dispersion is larger on spending per capita than on spending as a percentage of cantonal GDP, while the opposite is true for inter-party dispersion. It is unclear whether there is any significance in this result.
}

18 The SVP is one of the largest parties at the federal level in Switzerland, as well as in many cantons. 


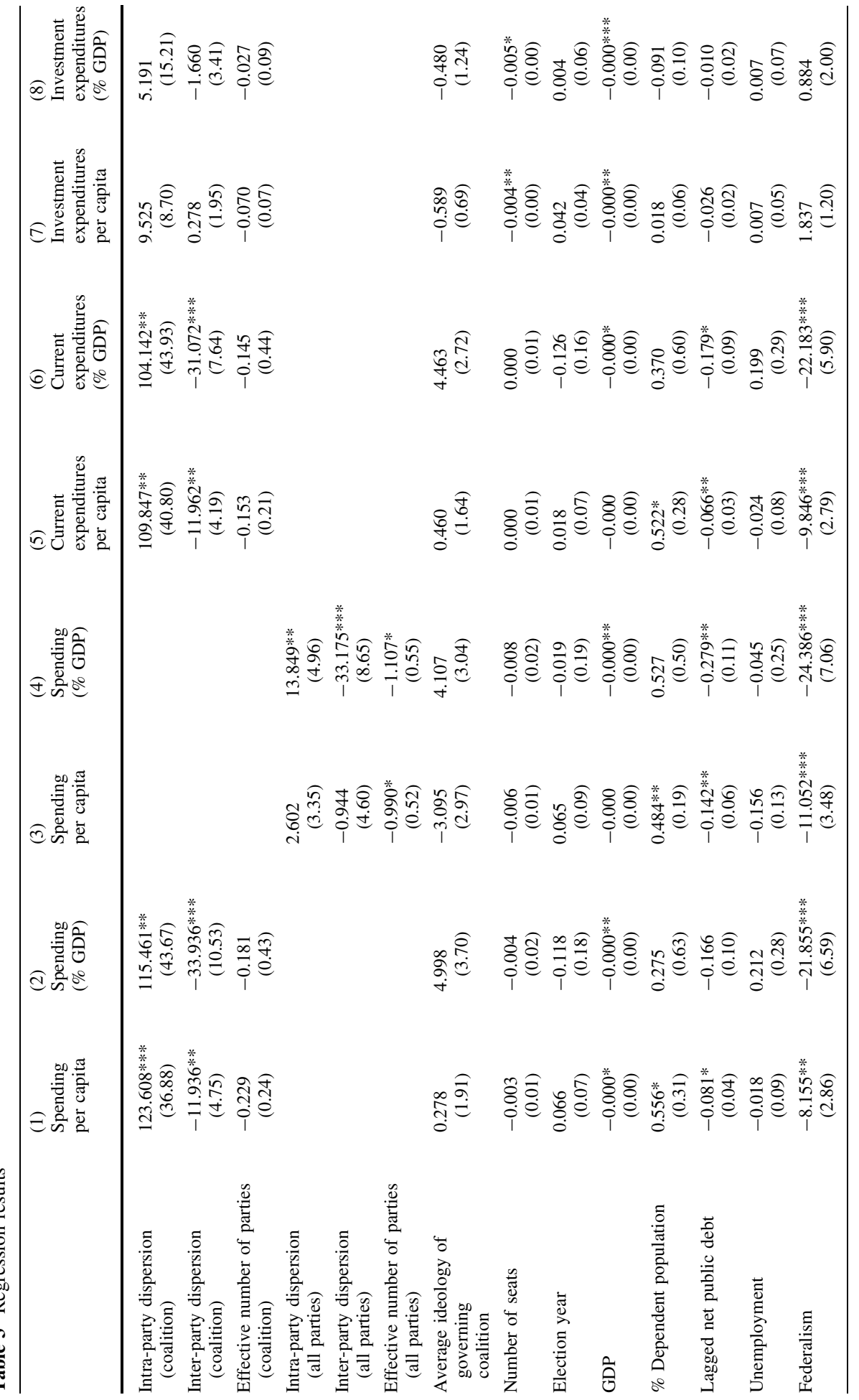




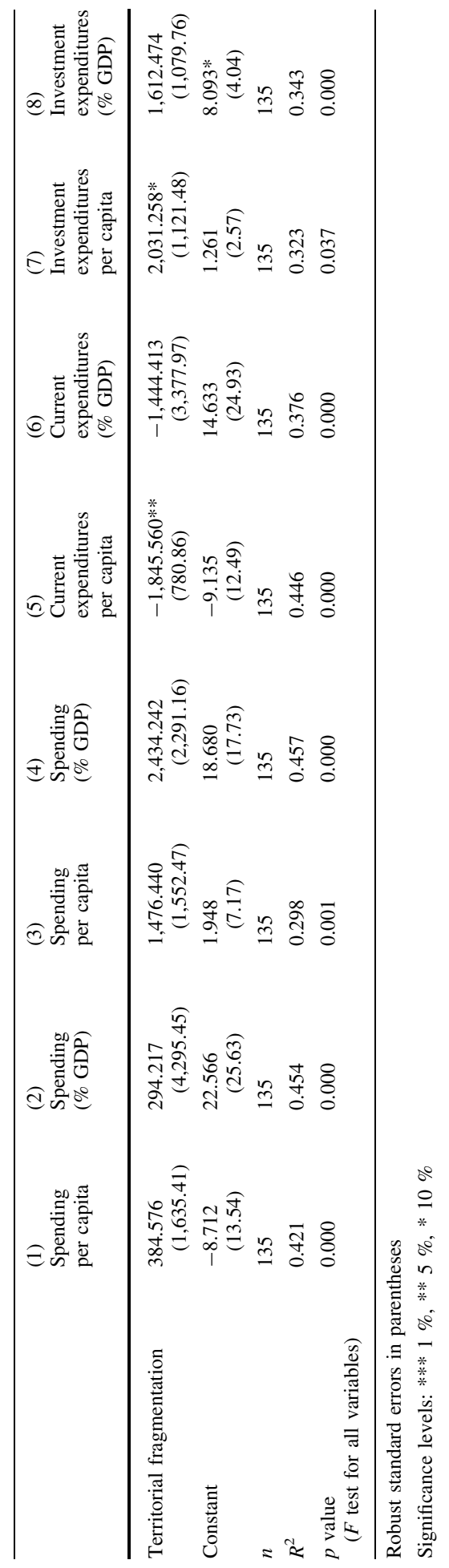


Some of our findings for the coalition group's inter- and intra-party dispersion are robust to this change of specification, although only for one of the two dependent variables, namely public spending as a share of GDP. We still observe a positive, albeit smaller effect of intra-party dispersion on public spending, and a negative effect of the coalition's interparty dispersion on public spending. We can summarize the results obtained so far as follows:

Result 1 Larger intra-party and lower inter-party ideological dispersion are both associated with more public spending.

The results regarding inter-party dispersion are somewhat different from the results of Eslava and Nupia (2010), who found that ideological dispersion, when measured as the standard deviation of the ideological scores of the main parties in government, tended to increase public spending. They rely on the common-pool argument, arguing that this ideological polarization was a catalyst in the relationship between political fragmentation and public spending. In a coalition government, it is true that a larger number of parties should lead to more spending, owing to the common-pool problem. It is also true that in countries where the coalition government can lose a legislative vote of confidence, thus being ousted from office, greater inter-party ideological dispersion between the coalition members should lead to more spending. Indeed, in these cases, the member parties have incentives to please everyone, thereby maintaining the coalition's strength. However, if such confidence votes are not held, as in Switzerland, incentives for cooperation are weaker, and inter-party ideological dispersion should reduce spending as parties have less common ground. Note also the contrast between intra- and inter-party dynamics. Between parties, the incentives for cooperation are weak, thus more different partners will be less likely to cede ground to one another. Within parties, the incentives for cooperation are much stronger; party leaders will thus be more likely to cede ground to party activists or factions.

In a subset of the models considered, we observe a negative impact of the effective number of political parties on public spending. This result is consistent with the argument for interparty ideological dispersion detailed above. However, this result is significant only at the $10 \%$ level. We also find that the average ideological score of the coalition group does not affect spending. However, the level of fiscal decentralization does affect public spending negatively, which is consistent with existing literature (including Switzerland).

One issue that can crop up in our analysis is that politicians may be office-seekers instead of motivated by ideology. In this case, one could argue that the policy preferences measured by electoral surveys (such as Smartvote) are irrelevant, and that politicians will decide to implement a different policy once elected. In this situation, we would have measurement errors in our variables of interest. This problem, however, may be of little importance in Switzerland. In fact, Schwarz et al. (2010) study the statements of candidates before and after elections, and find that political congruence in Switzerland reaches $85 \%$.

In Sect. 3, we argued that ideological dispersion could affect public spending by offering opportunities for more or less logrolling. It is also possible that exchanging votes is easier for projects that are not too distant in time. Indeed, as politicians in Switzerland are not professionals, their tenures are often expected to be relatively short. For this reason, a given politician will not want to enter a vote exchange agreement with another politician for a project that could be subject to votes only much later. Instead, they agree to help each other with projects that occur in the short term (for example, to keep some already-existing government project running). In terms of public spending, we should thus expect that logrolling is prevalent mainly in current spending, and not so much for investment expenditures.

To test that hypothesis, we use data for spending disaggregated according to their shortor long-term characteristics. Our results are summarized in columns 5-8 of Table 3. We 


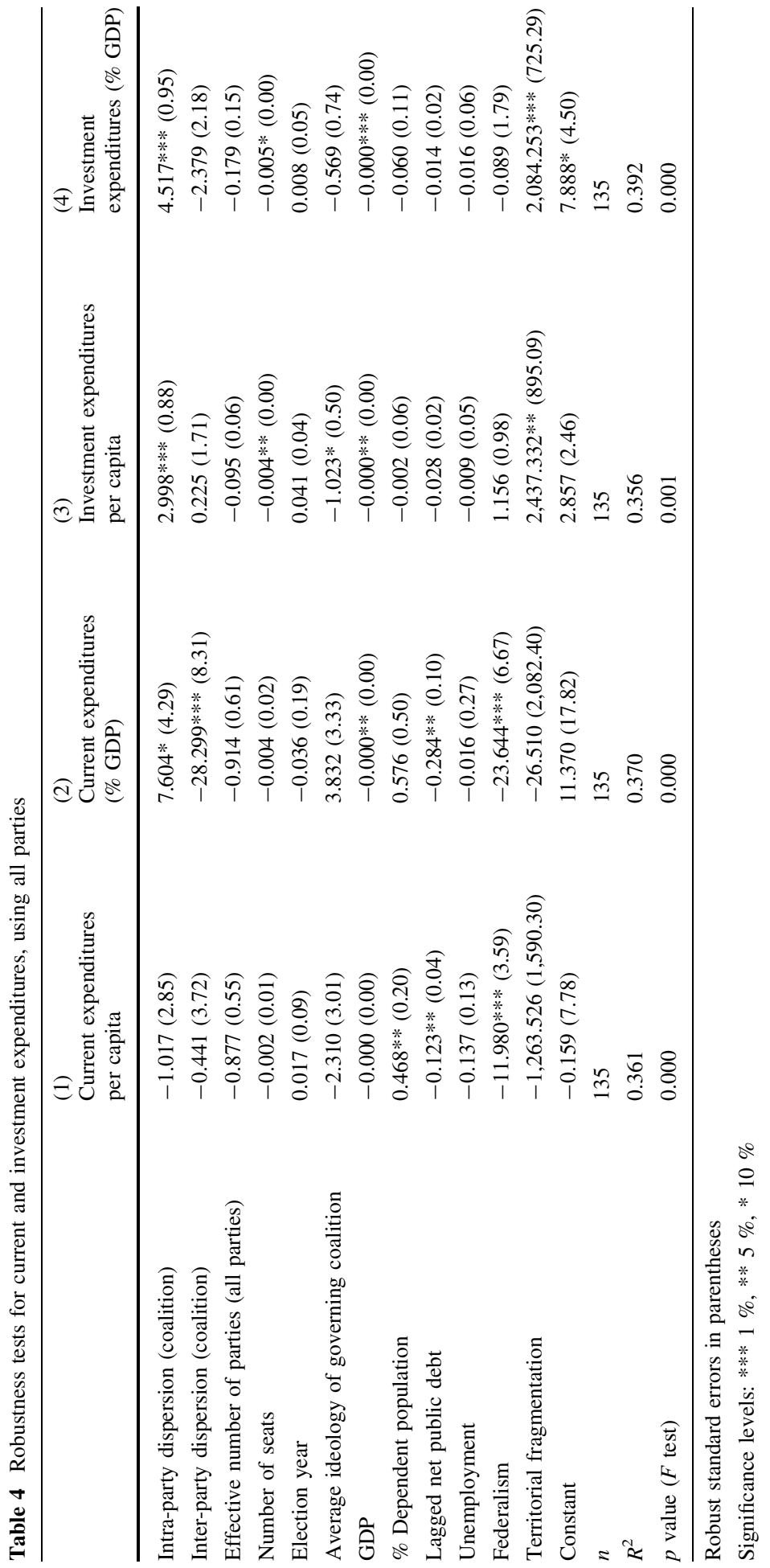


find that our two ideological dispersion variables impact current expenditures, with the same signs reported previously (namely, intra-party dispersion increases current expenditures, while inter-party dispersion reduces it). However, we find almost no impact on investment expenditures. Our model thus offers some support for the hypothesis that politicians forge logrolling agreements especially on short-term spending, but not on longer-term commitments.

Table 4 provides robustness tests using all parties rather than coalition partners only. The results hold for current expenditures, but only as a share of GDP. We obtained the same results when conducting this robustness test on total public spending. Interestingly, when all parties are included, we find a positive effect of intra-party dispersion on investment expenditures. We can summarize this second finding as:

Result 2 Ideological dispersion tends to have a greater effect on current expenditures than on investment expenditures.

\section{Conclusion}

In this paper, we have made two main contributions to the literature on the impact of political fragmentation on public spending, both showing that ideology and intra-party politics matter. First, we have shown that intra- and inter-party ideological dispersion both have an impact on public spending. In particular, intra-party dispersion is associated with more public spending, while inter-party dispersion is associated with less public spending. A corollary to this finding is that intra-party politics matter. This result is especially important, given that the previous literature mostly abstracts from ideological dispersion within parties. Our second finding is that ideological dispersion is especially relevant for current expenditures, and not so much for investment expenditures. We explain this result based on the fact that politicians are concerned mostly with short-term projects when agreeing to exchange votes with their colleagues.

Social scientists have already shown that intra-party politics matters for political outcomes. They have also shown that political fragmentation affects public spending. Our contribution rests at the intersection of these two sets of results. We believe that considering political parties as fragmented units themselves is important in understanding the budgeting process in governments and parliaments. Our paper is a first step in this direction. We have provided some theoretical background on these processes, along with empirical evidence.

One issue in our analysis may be measurement errors in the independent variables. Indeed, ideology is difficult to gauge. To confirm our results, one interesting avenue for future research would be to replicate our method using data from other countries. For example, the US also features a system in which the legislative and executive are clearly separated. Furthermore, parties in that country also show within-party ideological dispersion, even more so nowadays.

Acknowledgments The authors would like to thank Julien Fiechter for access to data from Smartvote surveys, Mark Schelker for Swiss institutional data, as well as participants at the Sinergia seminar in St. Gallen, at a seminar at the University of Fribourg, three anonymous referees, Roger Couture, and the editor for helpful comments.

\section{Appendix: Results using total variance as the variable of interest}

See the Table 5 . 


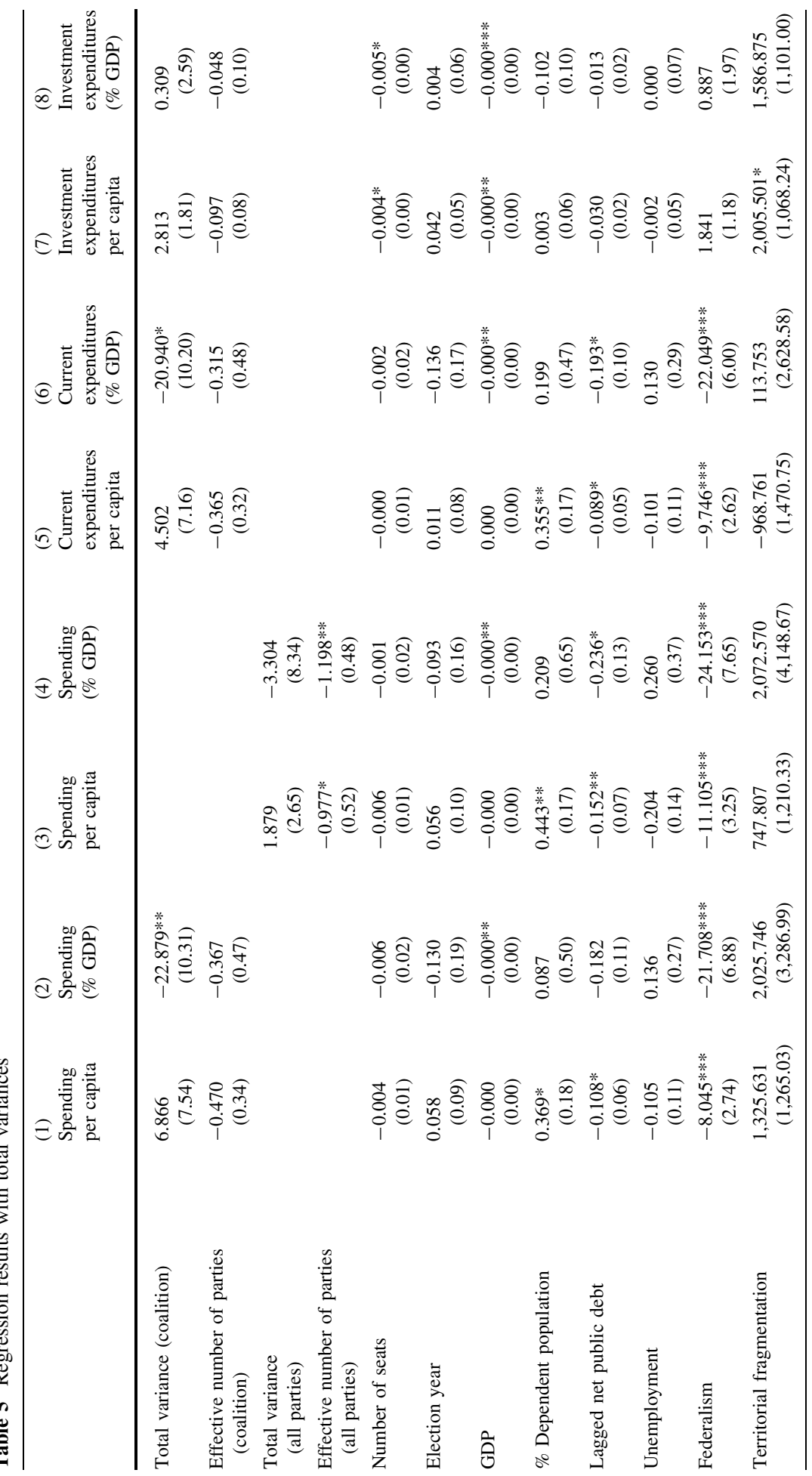




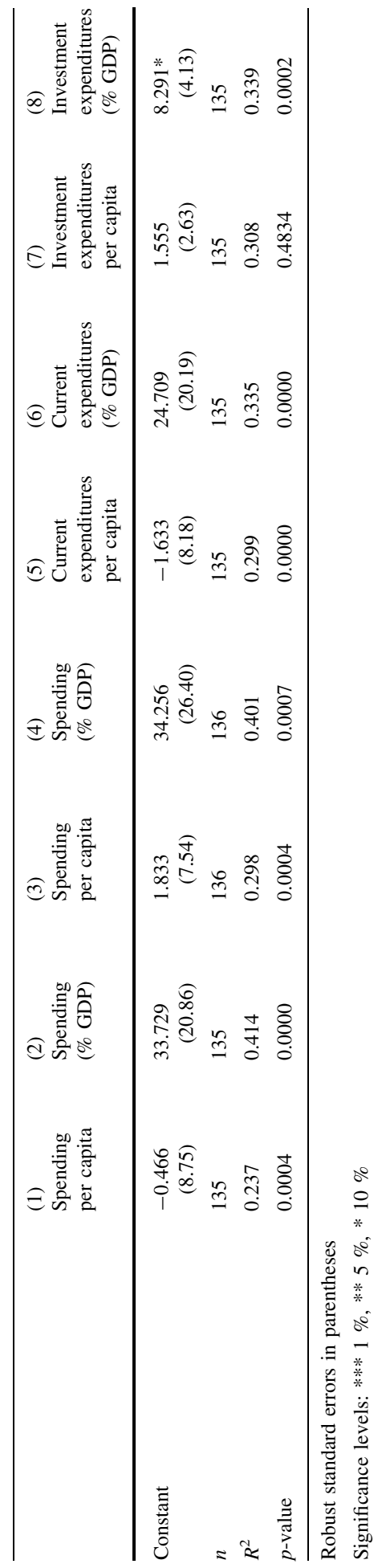




\section{References}

Alesina, A., \& Drazen, A. (1991). Why are stabilizations delayed. American Economic Review, 81(5), 1170-1188.

Alesina, A., \& Tabellini, G. (1990). A positive theory of fiscal deficits and government debt. The Review of Economic Studies, 57(3), 403-414.

Bachtiger, A., Schwarz, D., \& Lutz, G. (2006). Parliamentary practices in presidentialism? A Swiss perspective on governance in a separation of powers framework. In Paper prepared for the Joint Sessions of the ECPR.

Back, H. (2008). Intra-party politics and coalition formation: Evidence from Swedish local government. Party Politics, 14(1), 71-89.

Belloni, F. P., \& Beller, D. C. (1976). The study of party factions as competitive political organizations. The Western Political Quarterly, 29(4), 531.

Bettcher, K. E. (2005). Factions of interest in Japan and Italy: The organizational and motivational dimensions of factionalism. Party Politics, 11(3), 339-358.

Carrubba, C. J., \& Volden, C. (2000). Coalitional politics and logrolling in legislative institutions. American Journal of Political Science, 44(2), 255-277.

Ceron, A. (2011). Intra-party politics and party system. Factional conflict, cooperation and fission within Italian parties (PhD Thesis, Universitá degli Studi di Milano, 2011).

Church, C. H., \& Vatter, A. (2009). Opposition in consensual Switzerland: A short but significant experiment. Government and Opposition, 44(4), 412-437.

de Haan, J., \& Sturm, J.-E. (1997). Political and economic determinants of OECD budget deficits and government expenditures: A reinvestigation. European Journal of Political Economy, 13(4), 739-750.

de Haan, J., Sturm, J.-E., \& Beekhuis, G. (1999). The weak government thesis: Some new evidence. Public Choice, 101(3), 163-176.

Debus, M., \& Bräuninger, T. (2009). Intra-party factions and coalition bargaining. In D. Giannetti \& K. Benoit (Eds.), Intra-party politics and coalition government. London: Routledge.

Elgie, R., \& McMenamin, I. (2008). Political fragmentation, fiscal deficits and political institutionalisation. Public Choice, 136(3), 255-267.

Eslava, M., \& Nupia, O. (2010). Political fragmentation and government spending: Bringing ideological polarization into the picture. Documentos CEDE Working Paper.

Feld, L. P., \& Kirchgässner, G. (2000). Direct democracy, political culture, and the outcome of economic policy: A report on the Swiss experience. European Journal of Political Economy, 16(2), 287-306.

Feld, L. P., \& Kirchgässner, G. (2006). On the effectiveness of debt brakes: The Swiss experience. CREMA Working Paper number 2006-21.

Feld, L., Kirchgässner, G., \& Schaltegger, C. (2003). Decentralized taxation and the size of government: Evidence from Swiss state and local governments. CESifo Working Paper number 1087.

Freier, R., \& Odendahl, C. (2012). Do absolute majorities spend less? Evidence from Germany. DIW Discussion Paper number 1239.

Gilligan, T. W., \& Matsusaka, J. G. (1995). Deviations from constituent interests: The role of legislative structure and political parties in the states. Economic Inquiry, 33(3), 383-401.

Golden, M. A., \& Chang, E. C. C. (2011). Competitive corruption: Factional conflict and political malfeasance in postwar Italian Christian democracy. World Politics, 53(4), 588-622.

Hallerberg, M., Strauch, R., \& von Hagen, J. (2009). Forms of fiscal governance. Pittsburgh, PA: University of Pittsburgh.

Hertig, H. P. (1978). Party cohesion in the Swiss Parliament. Legislative Studies Quarterly, 3(1), 63-81.

Hetherington, M. J. (2006). Why trust matters: Declining political trust and the demise of American liberalism. Princeton, NJ: Princeton University Press.

Hix, S., Noury, A., \& Roland, G. (2009). Voting patterns and alliance formation in the European Parliament. Philosophical Transactions of the Royal Society, 364(1518), 821-831.

Horne, N. (2010). Hung parliaments and minority governments. Background Note (Australian Parliament).

Hug, S., \& Schulz, T. (2007). Left-right positions of political parties in Switzerland. Party Politics, 13(3), $305-330$.

Jeitzinger, B., \& Hohl, T. (1997). Measuring political preferences: Ratings for members of the Swiss National Council. Swiss Political Science Review, 3(4), 1-27.

Kerr, H. H. Jr. (1978). The structure of opposition in the Swiss Parliament. Legislative Studies Quarterly, 3(1), 51-62. 
Kontopoulos, Y., \& Perotti, R. (1999). Government fragmentation and fiscal policy outcomes: Evidence from OECD countries. In J. M. Poterba (Ed.), Fiscal institutions and fiscal performance (pp. 81-102). Chicago: University of Chicago Press.

Kriesi, H., \& Trechsel, A. H. (2008). The politics of Switzerland: Continuity and change in a consensus democracy. New York: Cambridge University Press.

Laakso, M., \& Taagepera, R. (1979). Effective number of parties: A measure with application to west Europe. Comparative Political Studies, 12(1), 3-27.

Ladner, A. (2001). Swiss political parties: Between persistence and change. West European Politics, 24(2), $123-144$.

Lanfranchi, P., \& Luthi, R. (1999). Cohesion of party groups and interparty conflict in the Swiss Parliament: Roll call voting in the national council. In S. Bowler, D. M. Farrell \& R. S. Katz (Eds.), Party discipline and parliamentary government. Columbus, $\mathrm{OH}$ : Ohio State University Press.

Laver, M., \& Shepsle, K. A. (1990). Government coalitions and intraparty politics. British Journal of Political Science, 20(4), 489-507.

Lindqvist, E., \& Östling, R. (2010). Political polarization and the size of government. American Political Science Review, 104(3), 543-565.

Maer, L. (2010). Hung parliaments. UK House of Commons Library Reports number SN/PC/04951.

Miller, N. R. (1999). Logrolling. In P. B. Clark and J. Foweraker (Eds.), The encyclopedia of democratic thought. London: Routledge.

Mulas-Granados, C. (2003). The political and economic determinants of budgetary consolidation in Europe. European Political Economy Review, 1(1), 15-39.

Müller, W. C., \& Strom, K. (2003). Coalition governments in western Europe. Oxford: Oxford University Press.

Padovano, F., \& Venturi, L. (2001). Wars of attrition in Italian government coalitions and fiscal performance: 1948-1994. Public Choice, 109(1), 15-54.

Pedersen, H. H. (2010). How intra-party power relations affect the coalition behaviour of political parties. Party Politics, 16(6), 737-754.

Perotti, R., \& Kontopoulos, Y. (2002). Fragmented fiscal policy. Journal of Public Economics, 86(2), 191-222.

Persson, T., \& Svensson, L. E. (1989). Why a stubborn conservative would run a deficit: Policy with timeinconsistent preferences. The Quarterly Journal of Economics, 104(2), 325-345.

Poterba, J. M. (1994). State responses to fiscal crises: The effects of budgetary institutions and politics. Journal of Political Economy, 102(4), 799-821.

Ricciuti, R. (2004). Political fragmentation and fiscal outcomes. Public Choice, 118(3), 365-388.

Roubini, N., \& Sachs, J. D. (1989). Government spending and budget deficits in the industrial economies. NBER Working Paper number 2919.

Rowley, C. K., Shughart, W. F., \& Tollison, R. D. (2002). The international library of critical writings in economics: The economics of budget deficits. Elgar.

Rudolph, T. J., \& Evans, J. (2005). Political trust, ideology, and public support for government spending. American Journal of Political Science, 49(3), 660-671.

Schaltegger, C. A., \& Feld, L. P. (2004). Do large cabinets favor large governments? Evidence from Swiss sub-federal jurisdictions. CESifo Working Paper Series number 1294.

Schwarz, D., Schädel, L., \& Ladner, A. (2010). Pre-election positions and voting behaviour in parliament: Consistency among Swiss MPs. Swiss Political Science Review, 16(3), 533-564.

Spolaore, E. (1993). Macroeconomic policy, institutions and efficiency (PhD Thesis, Harvard University, 1993).

Tavares, J. (2004). Does right or left matter? Cabinets, credibility and fiscal adjustments. Journal of Public Economics, 88(12), 2447-2468.

Tsebelis, G. (2002). Veto players: How political institutions work. Princeton, NJ: Princeton University Press.

Volkerink, B., \& De Haan, J. (2001). Fragmented government effects on fiscal policy: New evidence. Public Choice, 109(3), 221-242.

Warwick, P. V. (2000). Policy horizons in west European parliamentary systems. European Journal of Political Research, 38(1), 37-61.

Weingast, B. R., Shepsle, K. A., \& Johnsen, C. (1981). The political economy of benefits and costs: A neoclassical approach to distributive politics. The Journal of Political Economy, 89(4), 642-664.

Zuckerman, A. S. (1979). The politics of faction: Christian democratic rule in Italy. New York: Yale University Press. 